\title{
Properties of intact and univalent (Fab) antibodies raised against isolated, solubilized, mouse zonae pellucidae
}

\author{
R. J. Aitken, E. Holme, D. W. Richardson and M. Hulme \\ M.R.C. Unit of Reproductive Biology, Centre for Reproductive Biology, 37 Chalmers Street, \\ Edinburgh EH3 $9 E W$, U.K.
}

\begin{abstract}
Summary. Intact and univalent antibodies were prepared against mechanically isolated mouse zonae pellucidae solubilized in a variety of ways (heat, low $\mathrm{pH}, \mathrm{SDS}$, urea and trypsin). The antisera bound avidly and specifically to solubilized iodinated zona antigens and the intact zona structure.

When the concentrations of immunoreactive Fab material in the intact and univalent antibody preparations were equalized and compared for their ability to block the sperm-binding stage of fertilization, only the intact $\gamma$-globulin preparations possessed antifertility activity. These results indicate that antibodies raised against intact solubilized zonae pellucidae block fertilization by cross-linking antigens on the outer zona surface, thereby indirectly masking the sperm receptor sites. The integrity of these surface components did not appear to be affected by solubilization procedures that disrupt non-covalent bonds (heating, low pH, SDS and urea) although they did appear to be adversely affected by trypsin treatment.

None of the antisera tested contained antibodies directed against the sperm receptor site indicating that these critical components lack immunogenicity.
\end{abstract}

\section{Introduction}

The feasibility of regulating fertility through the induction of immunity against the zona pellucida has been demonstrated in active immunization models employing cross-reacting heterospecific zona antigens as the immunogen (Gwatkin, Williams \& Carlo, 1977; Gwatkin \& Williams, 1978; Aitken et al., 1981; Aitken \& Richardson, 1981a, b). The population of antibodies responsible for inducing infertility in these circumstances is thought to be that directed against the highly antigenic, carbohydrate-rich outer surface of the zona pellucida (Aitken \& Richardson, 1980). Experiments with antisera raised against mechanically isolated intact mouse zonae pellucidae have revealed that such antisera block the sperm-binding stage of fertilization by cross-linking antigenic sites on the zona surface and non-specifically masking the receptors for spermatozoa (Aitken \& Richardson, 1981c). In these studies there was no evidence to suggest that antisera raised against intact zonae contain antibodies directed against the sperm receptors themselves. This was a disappointing finding since these receptors are not only the most important biological components of the zona but also the most promising targets for contraceptive purposes (Aitken \& Richardson, 1980).

It is possible that the sperm-binding sites are of low antigenicity as suggested by the studies of Ahuja \& Tzartos (1981) who used univalent antibodies raised against hamster ovarian homogenates. An alternative explanation is that the sperm receptors are so positioned within the intact zona structure that they are not adequately exposed to the immune system of the host. 
However, solubilization of the zona pellucida under denaturing conditions (heat, urea, low $\mathrm{pH}$, SDS) is known to liberate high concentrations of biologically active receptors, capable of interfering with sperm-egg interactions in vitro (Gwatkin \& Williams, 1976; Bleil \& Wassarman, 1980b).

The purpose of the present study was therefore to use univalent antibody probes to investigate whether antisera raised against mechanically isolated zonae, which had been solubilized in several different ways, contained antibodies directed against the sperm-binding sites or relied entirely upon steric hinderance for their antifertility effects.

\section{Materials and Methods}

\section{Production of antisera}

Cumulus-free mouse ova were prepared as previously described (Aitken \& Richardson, 1981b) and the zonae were isolated with the aid of hand-drawn micropipettes with an internal diameter of about $50 \mu \mathrm{m}$. Exactly 1500 isolated zonae (equivalent to $7.2 \mu \mathrm{g}$ protein according to Bleil \& Wassarman, 1980a) were solubilized in $80 \mu \mathrm{l}$ of medium for each immunizing injection. The solubilization procedures were: (1) heating to $68^{\circ} \mathrm{C}$ (Cholewa-Stewart \& Massaro, 1972) in Dulbecco's phosphate-buffered saline, PBS, $\mathrm{pH} 7.2$ (Flow Laboratories, Irvine, Scotland); (2) $0.5 \%$ sodium dodecyl sulphate (SDS) at $37^{\circ} \mathrm{C}$; (3) $8 \mathrm{M}$-urea in PBS at $37^{\circ} \mathrm{C}$; (4) $0.15 \%$ trypsin in PBS at $37^{\circ} \mathrm{C}$; and (5) $5.4 \mathrm{~mm}$-adenosine triphosphate, pH 3.6, in $0.9 \%(\mathrm{w} / \mathrm{v}) \mathrm{NaCl}$ (Brun \& Psychoyos, 1972) at $37^{\circ} \mathrm{C}$. The immunization schedule involved a primary intramuscular injection with Freund's complete adjuvant, an identical booster 14 days later and after a further 14 days a final injection of immunogen administered intravenously. The rabbits were bled from a marginal ear vein 7 and 9 days after the last injection. The samples were checked for the presence of anti-zona antibodies by the indirect immunofluorescence technique (Aitken \& Richardson, $1981 \mathrm{~b}$ ) and subsequently heated to $56^{\circ} \mathrm{C}$ for $30 \mathrm{~min}$ to inactivate complement before being divided into $1-\mathrm{ml}$ fractions and stored at $-20^{\circ} \mathrm{C}$.

A control antiserum was prepared against mouse lymphocytes using the procedures described by Morton, Hegh \& Clunie (1974).

\section{Preparations of $\gamma$-globulin}

The $\gamma$-globulin fraction of each antiserum was concentrated by sodium sulphate precipitation (Heide \& Schwick, 1978). To $5 \mathrm{ml}$ antiserum an equal volume of $36 \%(\mathrm{w} / \mathrm{v})$ sodium sulphate in $0.2 \mathrm{M}$-sodium phosphate buffer, $\mathrm{pH} 8.0$, was added and incubated for $1 \mathrm{~h}$ at $25^{\circ} \mathrm{C}$ in a water bath. The precipitated $\gamma$-globulin was centrifuged at $2500 \mathrm{~g}$ at $25^{\circ} \mathrm{C}$ and the pellet was re-suspended in $10 \mathrm{ml} 18 \%(\mathrm{w} / \mathrm{v})$ sodium sulphate in $0.1 \mathrm{M}$-phosphate buffer, $\mathrm{pH} 8.0$. The precipitate was centrifuged as before and re-suspended in $2 \mathrm{ml} 0.1 \mathrm{M}$-phosphate buffer, $\mathrm{pH} \mathrm{8.0}$. The $\gamma$-globulin preparation was dialysed overnight against distilled water and then washed with $30 \mathrm{ml} 0.9 \%(\mathrm{w} / \mathrm{v}) \mathrm{NaCl}$ by ultrafiltration through UM10 membranes (Amicon, Woking, England) with a molecular weight exclusion of 10000 . The $\gamma$-globulin solutions were finally concentrated by ultrafiltration to $20 \mathrm{mg} / \mathrm{ml}$ as determined by absorption at $280 \mathrm{~nm}$ using BSA standards.

\section{Preparation of Fab fragments}

Univalent Fab fragments were prepared by papain digestion of the concentrated $\gamma$-globulin fraction followed by Sephadex G-75 chromatography (Porter, 1959; Ahuja \& Tzartos, 1981). The protein peak eluting with a molecular weight of 50000 was finally concentrated to a volume of $1 \mathrm{ml}$ by dialysis against solid sucrose and run against a goat anti-rabbit $\mathrm{Fab}$ antiserum (Miles, 
Slough, England) in radial immunodiffusion plates to confirm the presence of Fab fragments. The absence of bivalent contamination of these preparations was indicated by the molecular weight of the Fab fractions (50000) and their inability to produce a precipitate on the zona surface despite an apparent capacity to bind to the zona pellucida by indirect immunofluorescence analysis (Ahuja \& Tzartos, 1981).

\section{Indirect immunofluorescence}

Cumulus-free mouse ova were incubated in $20 \mu$ droplets of serially diluted antibody under paraffin oil for $30 \mathrm{~min}$ at $37^{\circ} \mathrm{C}$. The ova were subsequently taken through 4 washes of PBS and then incubated for $30 \mathrm{~min}$ at $37^{\circ} \mathrm{C}$ in the dark with a 1:10 dilution of goat anti-rabbit Fab antiserum conjugated to fluorescein isothiocyanate (Gibco, Paisley, Scotland). The ova were washed 4 times in PBS after exposure to labelled antibody, transferred in a $5 \mu 1$ drop to the centre of an acetone-cleaned slide and covered with a $20 \times 20 \mathrm{~mm}$ coverslip mounted on 4 paraffin wax supports. The ova were then observed under dark-field u.v.-blue illumination with a Leitz Ortholux II microscope equipped with a 50-W mercury lamp, a KP490 interference filter, a secondary K530 green filter and a BG-38 red suppressor filter. The last doubling dilution at which the immunofluorescence response was observed was taken as the titre and 7-11 ova were used at each dilution. Control incubations contained an anti-mouse lymphocyte antiserum.

\section{Immunoprecipitation}

Cumulus-free ova were incubated in serially diluted antibody, washed 4 times in PBS and examined under dark-field illumination with a Leitz Ortholux II microscope. The last doubling dilution at which a surface precipitate was observed was taken as the titre and 7-12 ova were used at each dilution. Control incubations contained an anti-mouse lymphocyte antiserum.

\section{Pronase solubilization}

Cumulus-free ova were incubated in the presence of $\gamma$-globulin for $30 \mathrm{~min}$ at $37^{\circ} \mathrm{C}$ before being washed in PBS and transferred to $0.1 \%$ pronase for solubilization. The ova were subsequently examined every 2 min until the zonae pellucidae surrounding $50 \%$ of the ova had solubilized (Inoue \& Wolf, 1974). The solubilization time was expressed as a percentage increase over the time taken to dissolve untreated zonae in the same enzyme solution and 7-12 ova were used for each determination.

\section{Sperm binding to the zona pellucida}

The ability of anti-zona antisera to inhibit the sperm-binding stage of fertilization was assessed using the procedures described by Aitkin \& Richardson (1981b) and 10-15 ova were scored for each determination.

\section{Radioimmunoassay}

The iodination procedure adopted for this study is based on the description of Palm, Sacco, Syner \& Subramanian (1979). Exactly $30 \mu \mathrm{l} 0.05 \mathrm{M}-\mathrm{NaH}_{2} \mathrm{PO}_{4}(\mathrm{pH} \mathrm{7.5)}$ and $5 \mu \mathrm{l}(0.5 \mathrm{mCi})$ of carrier-free $\mathrm{Na}^{125} \mathrm{I}$ (Amersham International, Amersham, England) were added to 500 mechanically isolated mouse zonae solubilized by heating or exposure to low pH (5.4 mM-ATP) contained in $50 \mu \mathrm{l} 0.05 \mathrm{M}-\mathrm{NaH}_{2} \mathrm{PO}_{4}(\mathrm{pH} \mathrm{7.5)}$. Then $10 \mu \mathrm{l}$ of freshly prepared chloramine-T (1 $\mathrm{mg} / \mathrm{ml}$ in $0.05 \mathrm{M}-\mathrm{NaH}_{2} \mathrm{PO}_{4}$ ) were added to the mixture followed $45 \mathrm{sec}$ later by $500 \mu \mathrm{l}$ of freshly prepared $\mathrm{Na}_{2} \mathrm{~S}_{2} \mathrm{O}_{5}\left(0.4 \mathrm{mg} / \mathrm{ml}\right.$ in $\left.0.05 \mathrm{M}-\mathrm{NaH}_{2} \mathrm{PO}_{4}\right)$ to arrest the iodination reaction. The 
iodinated zona material was immediately separated from unreacted ${ }^{125} \mathrm{I}$ by passage through a $1 \times$ $20 \mathrm{~cm}$ Biogel P-60 (Biorad, Richmond, U.S.A.) column equilibrated with $0.05 \mathrm{M}-\mathrm{NaH}_{2} \mathrm{PO}_{4}$. The specific activities of the radiolabelled tracers were calculated and found to be $0 \cdot 1 \mu \mathrm{Ci} /$ zona $(20 \cdot 8$ $\mu \mathrm{Ci} / \mu \mathrm{g}$ protein) and $0.12 \mu \mathrm{Ci} /$ zona $(25 \mu \mathrm{Ci} / \mu \mathrm{g}$ protein) for the heat- and ATP-solubilized material respectively. The interaction between the iodinated zona tracers and the anti-zona antisera was analysed following serial dilution of the $\gamma$-globulin fraction from 1:100 to 1:2000 in serum-supplemented buffer, $\mathrm{pH} 7.0\left(0.01 \mathrm{M}-\mathrm{KH}_{2} \mathrm{PO}_{4}, 0.14 \mathrm{M}-\mathrm{NaCl}, 0.05 \mathrm{M}-\mathrm{Na}_{2} \mathrm{EDTA}, 0.1 \%\right.$ normal rabbit serum). To $100 \mu$ of each $\gamma$-globulin dilution was added $100 \mu$ phosphate-gelatin buffer, $\mathrm{pH} 7.0\left(0.01 \mathrm{M}-\mathrm{KH}_{2} \mathrm{PO}_{4}, 0.14 \mathrm{M}-\mathrm{NaCl}, 0.1 \%\right.$ gelatin, $0.1 \%$ merthiolate $)$ and $100 \mu \mathrm{l}$ of iodinated tracer giving 10000 c.p.m. $(0.4 \mathrm{ng}$ zona protein $)$. Duplicate tubes were incubated for 3 days at $4^{\circ} \mathrm{C}$ after which $100 \mu \mathrm{l}$ donkey anti-rabbit $1 \mathrm{gG}$ antiserum (Scottish Antibodies Production Unit, Carluke, Scotland), diluted 1:15 with phosphate-gelatin buffer were added and incubated for $18 \mathrm{~h}$ to precipitate IgG-bound tracer. The tubes were subsequently centrifuged at $2500 \mathrm{~g}$ for $30 \mathrm{~min}$ at $4^{\circ} \mathrm{C}$ and the supernatant discarded. The radioactivity present in the precipitated material was counted on a 1270 Rackgamma counter (LKB, Wallac, South Croydon, England) for $1 \mathrm{~min} /$ tube. Control tubes containing tracer and a serially diluted $\gamma$-globulin preparation derived from a rabbit anti-mouse lymphocyte serum were run in parallel.

\section{Results}

As shown in Text-fig. 1, with the exception of the trypsin-treated material all of the remaining zona preparations induced the formation of antibodies that bount avidly to the labelled antigens and gave parallel antibody dilution curves. Comparison of Text-figs $1(\mathrm{a})$ and $1(\mathrm{~b})$ reveals that in each experiment the specific binding was greatest when the tracer and antiserum were generated through the same solubilization technique (ATP in Text-fig. 1(a) and heat in Text-fig. 1(b)). In contrast, antibodies raised against trypsin solubilized material exhibited a poor or an undetectable affinity for the ATP and heat solubilized tracers respectively. In these experiments non-specific binding of the labelled antigens to the $\gamma$-globulin fraction of a control rabbit

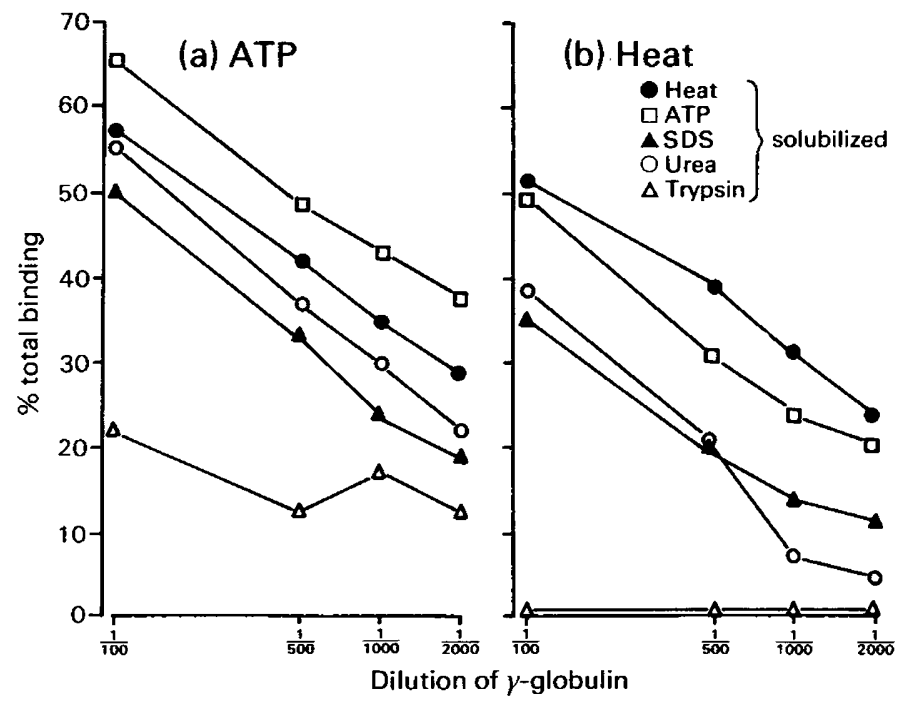

Text-fig. 1. Binding of iodinated mouse zona tracers (a, ATP solubilized; b, heat solubilized) to the $\gamma$-globulin fraction of antisera raised against mechanically isolated zonae solubilized in various ways. 
anti-mouse lymphocyte preparation represented about $10 \%$ of the total counts bound at each equivalent dilution of anti-zona antiserum.

All of the anti-zona $\gamma$-globulin preparations were also observed to bind specifically to the intact zona pellucida by indirect immunofluorescence and produced a precipitate on the outer zona surface (Table 1). Interaction between the antisera raised against solubilized zonae and the intact structure was also indicated by the stabilizing effect each antiserum exerted on the induction of zona-lysis by pronase. As Table 1 indicates, the cross-linking activity of all the anti-zona antisera tested so stabilized the structure of the zonae pellucidae that their resistance to proteolytic digestion was considerably enhanced.

Table 1. Interaction between the $\gamma$-globulin fraction of antisera raised against isolated solubilized zonae pellucidae and the intact structure

\begin{tabular}{lccc}
\hline \multicolumn{1}{c}{ Antiserum } & $\begin{array}{c}\text { Indirect } \\
\text { immunofluorescence }\end{array}$ & $\begin{array}{c}\text { Increased } \\
\text { resistance to } \\
\text { zona }\end{array}$ \\
\hline ATP solubilized & $1: 512$ & $1: 256$ & 329 \\
Heat solubilized & $1: 1024$ & $1: 1024$ & 212 \\
Urea solubilized & $1: 512$ & $1: 128$ & 300 \\
SDS solubilized & $1: 256$ & $1: 64$ & 47 \\
Trypsin solubilized & $1: 128$ & $1: 32$ & 192 \\
Control & 0 & 0 & 0 \\
\hline
\end{tabular}

Assessment of the biological activity of the $\gamma$-globulin preparations in the sperm binding assay indicated that, with the exception of the control anti-mouse lymphocyte antiserum, all of the remaining antisera significantly inhibited the sperm-binding stage of fertilization (Table 2). The least effective antiserum was that raised against trypsin-solubilized zonae while all the remaining $\gamma$-globulin preparations suppressed sperm binding to $<20 \%$ of the corresponding control value. The degree of biological activity exhibited by the anti-zona antisera showed a highly significant correlation with antibody titre whether measured by radioimmunoassay $(P<$ $0.001)$, indirect immunofluorescence $(P<0.001)$ or immunoprecipitation techniques $(P<$ 0.001 ).

Table 2. Inhibition of sperm binding to the zonae pellucidae surrounding unfertilized eggs with the $\gamma$-globulin fraction of antisera raised against isolated solubilized zonae

\begin{tabular}{cccc}
\hline $\begin{array}{c}\text { Antigen } \\
\text { solubilization }\end{array}$ & \multicolumn{2}{c}{ Sperm binding $/ \mathrm{mm}^{2}$ zona surface } & $\begin{array}{c}\text { \% Inhibition } \\
\text { of binding }\end{array}$ \\
\cline { 2 - 4 } & Control & Treated & 0 \\
\hline Control (ALS) & $6585 \pm 402$ & $8754 \pm 1510$ & $95^{* * *}$ \\
ATP & $6585 \pm 402$ & $333 \pm 144$ & $93^{* * *}$ \\
Heat & $5204 \pm 295$ & $372 \pm 124$ & $89^{* * *}$ \\
Urea & $3446 \pm 313$ & $367 \pm 71$ & $84^{* * *}$ \\
SDS & $6677 \pm 593$ & $1069 \pm 208$ & $15^{*}$ \\
Trypsin & $6925 \pm 691$ & $5923 \pm 1017$ & \\
\hline
\end{tabular}

Values are mean \pm s.e.m.

Significantly different from control values: ${ }^{*} P<0.05 ;{ }^{* * *} P<0.001$.

The Fab univalent antibody preparations also reacted specifically with the intact zona pellucida by indirect immunofluorescence (1:16 for ATP, 1:32 for heat, 1:64 for urea, 1:16 for 
SDS, $1: 2$ for trypsin, 0 for controls). However, in contrast to the intact $\gamma$-globulins these univalent preparations, deprived of the capacity to cross-link antigens, were incapable of producing a precipitate on the outer zona surface.

To make a valid comparison between the ability of intact and univalent anti-zona preparations to inhibit sperm binding to the zona pellucida it is crucial that the concentration of immunoreactive $\mathrm{Fab}$ material in each preparation is equalized. Equalization of the concentration of Fab fragments interacting with the intact zona pellucida was achieved by using the titres obtained by indirect immunofluorescence and a fluorescein-conjugated anti-rabbit Fab antiserum. From the results of the immunofluorescence analysis (Table 1 and above), the intact $\gamma$-globulin was diluted to make the immunoreactive Fab concentration equivalent with that of the univalent preparation, i.e. immunofluorescence activity subsequently extinguished at the same dilution. When the intact and univalent anti-zona antibody preparations were subsequently compared for their ability to inhibit sperm binding to the zona pellucida (Table 3,) only intact anti-zona antibodies possessed biological activity. Relative to the within-assay controls, none of the Fab preparations significantly inhibited sperm binding to the zona pellucida whereas all the diluted, intact $\gamma$-globulin preparations produced a significant inhibition. All of the intact anti-zona $\gamma$-globulin preparations produced a significant inhibition of sperm binding relative to the corresponding univalent Fab fractions.

Table 3. Influence of intact and univalent (Fab) antizona antibodies on the sperm binding capacity of the mouse zona pellucida

\begin{tabular}{cccc}
\hline \multirow{2}{*}{$\begin{array}{c}\text { Antigen } \\
\text { solubilization }\end{array}$} & \multicolumn{3}{c}{ Sperm binding $/ \mathrm{mm}^{2}$ zona surface } \\
\cline { 2 - 4 } & Untreated control & Univalent antibody & Intact antibody \\
\hline ATP & $6274 \pm 767$ & $6522 \pm 305^{\dagger+\dagger}$ & $4429 \pm 246^{* *}$ \\
Heat & $6677 \pm 593$ & $5351 \pm 210^{+\dagger}$ & $3336 \pm 215^{* *}$ \\
Urea & $6677 \pm 593$ & $6337 \pm 174^{\dagger \dagger}$ & $2507 \pm 202^{* *}$ \\
SDS & $6677 \pm 593$ & $6306 \pm 304^{\dagger}+\dagger$ & $3711 \pm 265^{* * *}$ \\
Trypsin & $6677 \pm 593$ & $5029 \pm 96^{\dagger}$ & $4555 \pm 168^{* *}$ \\
Control & $6677 \pm 593$ & $5151 \pm 191$ & $6743 \pm 551$ \\
Control & $6682 \pm 799$ & & \\
\hline
\end{tabular}

Values are mean \pm s.e.m.

Values significantly different from those of controls: ${ }^{* *} P<0.01,{ }^{* * *} P<0.001$.

Values significantly different from those with intact antibody: $† P<0.05,+\dagger+P<$ 0.001 .

\section{Discussion}

Antibodies raised against solubilized mouse zonae pellucidae bound avidly to solubilized zona antigens and the intact structure. The interaction between these antisera and intact zonae pellucidae was specifically mediated through the Fab portion of the immunoglobulin molecule.

All of the antisera tested appeared to contain antibodies, directed against the carbohydrate-rich outer surface of the zona pellucida (Nicolson, Yanagimachi \& Yanagimachi, 1975), which were capable of inducing the formation of an immunoprecipitate through the cross-linkage of surface antigens. The ability of each individual antiserum to induce this surface precipitate was directly related to its capacity to inhibit the sperm-binding stage of fertilization.

The concentration of antibodies capable of precipitate induction in each antiserum and its respective ability to disrupt sperm binding to the zona pellucida were correlated $(P<0.001)$. In addition univalent anti-zona antibodies, containing a concentration of immunoreactive Fab 
fragments similar to that of the intact antiserum but lacking the ability to form a surface precipitate, were incapable of inhibiting sperm binding. Antisera raised against intact mouse zonae pellucidae have also been shown to depend upon immunoprecipitate formation and consequent masking of the sperm receptor sites for their antifertility activity (Aitken \& Richardson, 1981c).

The nature of the solubilization techniques employed to generate these surface components for immunization did not appear to have a marked effect on their integrity. Most of the procedures used (heat, low $\mathrm{pH}$, urea, SDS) generated a high concentration of antibodies directed against the surface antigens which were active in precipitate formation and sperm-binding inhibition. The only exception was the trypsin solubilization technique which produced a low titre of antibodies directed against the surface antigens and was the least effective antiserum in terms of sperm-binding inhibition. Hence in contrast to the other solubilization techniques all of which disrupt non-covalent bonds, trypsin, a specific proteolytic enzyme, may well interfere with the integrity of the surface glycoproteins. The calculation of affinity constants using several such antisera and purified labelled surface antigens will be needed to confirm this point.

A comparison of sperm-binding inhibition after exposure to intact and univalent antibodies raised against solubilized zona material revealed that none of the antisera tested contained a significant concentration of antibodies directed against the sperm-binding site. An important element of the present investigation which was not considered in previous studies (Ahuja \& Tzartos, 1981) is that measures were taken to equalize the concentration of immunoreactive Fab material in the univalent and intact antibody preparations so that valid comparisons could be made with respect to their biological activity. It was considered critical in this respect to measure the interaction between the Fab portions of the immunoglobulin molecules and the intact zona structure because it is this interaction which determines the biological potency of a given antiserum. Indirect immunofluorescence and immunoprecipitation techniques are both capable of providing quantitative data on the concentration of antibodies interacting with the intact zona structure (Tsunoda, Sugie \& Mōri, 1979), although only the former is appropriate for comparing univalent and intact antibody preparations (univalent Fab preparations do not form immunoprecipitates). The radioimmunoassay procedure described in his study is capable of providing valuable data on the interaction between anti-zona antibodies and a solubilized, iodinated tracer, although the extent of this interaction depends to an unknown degree upon the nature of the solubilization procedure used to generate the tracer. For this reason the radioimmunoassay technique was not employed for the purpose of monitoring Fab concentrations on the intact and univalent antibody preparations.

The results obtained in this study clearly indicate that the sperm-binding site is lacking in immunogenicity. This interpretation fully accords with the conclusions drawn by Aitken \& Richardson (1981c) and Ahuja \& Tzartos (1981) in studies employing antisera raised against isolated, intact mouse zonae and homogenized hamster ovaries respectively. According to Bleil \& Wassarman $(1980 \mathrm{a}, \mathrm{b})$ the sperm receptor present in the mouse zona pellucida is a glycoprotein exhibiting a molecular weight of 83000 and it would seem unlikely that such a large molecule is completely without antigenicity. Similarly, it would seem unlikely that the solubilization procedures employed in this study disrupted the integrity of the sperm-receptor molecule. Gwatkin \& Williams (1976) have shown that heating the mouse zona pellucida to $65^{\circ} \mathrm{C}$ for $35 \mathrm{~min}$ results in the solubilization of a biologically active receptor and electrophoretic studies (R.J.A., unpublished observations) indicate that the 83000 molecular weight receptor component remains unaltered if the solubilization temperature is raised to $68^{\circ} \mathrm{C}$ as recommended by Cholewa-Stewart \& Massaro (1972). Heating hamster zonae pellucidae to boiling point appears to have no negative effect upon the biological potency of the receptor fraction (Gwatkin \& Williams, 1976). The mouse zona receptor also retains its biological activity when solubilized at a $\mathrm{pH}$ as low as 2.5 (Bleil \& Wassarman, 1980b) compared with the solubilization $\mathrm{pH}$ of 3.6 employed in the present study. In addition isolation of the 83000 molecular weight receptor 
component following solubilization of mouse zonae in 2\% SDS, subsequent electrophoresis and dialysis against urea (Bleil \& Wassarman, 1980a, b) is fully compatible with the retention of biological activity, suggesting that neither the SDS $(0.5 \%)$ nor the urea $(8 \mathrm{M})$ treatment employed in the present study should have disrupted the integrity of the receptor molecule. The influence of trypsin on mouse zona function is less certain and it is possible that this enzyme may have had a deleterious effect upon the integrity of the sperm receptor. This would seem unlikely, however, in view of the fact that exposure of mouse zonae pellucidae to trypsin at doses as high as $2 \mathrm{mg} / \mathrm{ml}$ stimulates the zona's capacity to bind spermatozoa (R. J. Aitken \& D. W. Richardson, unpublished observations) under carefully controlled conditions (Aitken \& Richardson, 1981b). Furthermore, these findings are in accord with the studies of Saling (1981) indicating that trypsin-like enzymes of sperm origin play a critical role in actually effecting the binding of spermatozoa to the zona surface.

The most likely explanation for the results obtained in this study is that while anti-zona antisera may interact with the solubilized 83000 molecular weight receptor component, the antibodies they contain do not bind directly to that portion of the molecule responsible for the sperm-binding properties. Awareness of the exact composition of the sperm-binding site and its immunogenic potential are absolutely crucial since the sperm receptor is likely to be the most potent target for immunocontraception within the zona pellucida (Aitken et al., 1981).

\section{References}

Ahuja, K.K. \& Tzartos, S.J. (1981) Investigation of sperm receptors in the hamster zona pellucida by using univalent (Fab) antibodies to hamster ovary. $J$. Reprod. Fert. 61, 257-264.

Aitken, R.J. \& Richardson, D.W. (1980) Immunization against zona pellucida antigens. In Immunological Aspects of Reproduction and Fertility Control, pp. 173-201. Ed. J. P. Hearn. MTP Press, Lancaster.

Aitken, R.J. \& Richardson, D.W. (1981a) Immunization of rats with cumulus-free mouse ova: induction of infertility and antibody titers. J. exp. Zool. 216, $149-158$.

Aitken, R.J. \& Richardson, D.W. (1981b) Measurement of the sperm binding capacity of the mouse zona pellucida and its use in the estimation of anti-zona antibody titres. J. Reprod. Fert. 63, 295-307.

Aitken, R.J. \& Richardson, D.W. (1981c) Mechanism of sperm-binding inhibition by anti-zona antisera. Gamete Res. 4, 41-47.

Aitken, R.J., Rudak, E.-A., Richardson, D.W., Dor, J., Djahanbakhch, O. \& Templeton, A.A. (1981) The influence of anti-zona and anti-sperm antibodies on sperm-egg interactions. J. Reprod. Fert. 62, 597606.

Bleil, J.D. \& Wassarman, P.M. (1980a) Structure and function of the zona pellucida: identification and characterization of the proteins of the mouse oocytes zona pellucida. Devl Biol. 76, 185-202.

Bleil, J.D. \& Wassarman, P.M. (1980b) Mammalian sperm-egg interaction: identification of a glycoprotein in mouse egg zonae pellucidae possessing receptor activity for sperm. Cell 20, 873-882.

Brun, J.L. \& Psychoyos, A. (1972) Dissolution of the rat zona pellucida by acidified media and blastocyst viability. J. Reprod. Fert. 30, 489-491.

Cholewa-Stewart, J. \& Massaro, E.J. (1972) Thermally induced dissolution of the murine zona pellucida. Biol. Reprod. 7, 166-169.
Gwatkin, R.B.L. \& Williams, D.T. (1976) Receptor activity of the solubilized hamster and mouse zona pellucida before and after the zona reaction. $J$. Reprod. Fert. 49, 55-59.

Gwatkin, R.B.L. \& Williams, D.T. (1978) Immunization of female rabbits with heat-solubilized bovine zonae: production of anti-zona antibody and inhibition of fertility. Gamete Res. 1, 19-26.

Gwatkin, R.B.L., Williams, D.T. \& Carlo, D.J. (1977) Immunization of mice with heat-solubilized hamster zonae: production of anti-zona antibody and inhibition of fertility. Fert. Steril. 28, 871-877.

Heide, K. \& Schwick, H.G. (1978) Salt fractionation of immunoglobulins. In Handbook of Experimental Immunology, Vol. 1, pp. 7.1-7.11. Ed. D. M. Weir. Blackwell, Oxford.

Inoue, M. \& Wolf, D.P. (1974) Solubility properties of the murine zona pellucida. Biol. Reprod. 10, 512518.

Morton, H., Hegh, V. \& Clunie, G.V.A. (1974) Immunosuppression detected in pregnant mice by the rosette inhibition test. Nature, Lond, 249, 459-460.

Nicolson, G.L., Yanagimachi, R. \& Yanagimachi, H. (1975) Ultrastructural localization of lectin binding sites on the zona pellucida and plasma membranes of mammalian eggs. J. Cell Biol. 66, 263-270.

Palm, V.S., Sacco, A.G., Syner, F.N. \& Subramanian, M.G. (1979) Tissue specificity of porcine zona pellucida antigen(s) tested by radioimmunoassay. Biol. Reprod. 21, 709-713.

Porter, R.R. (1959) The hydrolysis of rabbit gammaglobulin and antibodies with crystalline papain. Biochem. J. 73, 119-126.

Saling, P.M. (1981) Involvement of trypsin-like activity in binding of mouse spermatozoa to zonae pellucidae. Proc. natn. Acad. Sci. U.S.A. 78, 6231-6235.

Tsunoda, Y., Sugie, T. \& Móri, J. (1979) Quantitative determination of titres of antizona serum. $J$. exp. Zool. 207, 315-320. 